$$
\begin{gathered}
\text { バージャ一病における血液凝固・線溶 } \\
\text { 劉 } \\
\text { 向愁忠* }
\end{gathered}
$$

\title{
Blood coagulation and fibrinolysis in Buerger's disease
}

\author{
M. C. Liu*, T. T. Kim*, Akira TAKAHASHI*, \\ Kiyoshi MUKAI*, Takeshi OHSHIRO* and Goro KOSAKI*
}

Key words : Heparin resistance, Antisthronbin III, Buerger's disease

Buerger's disease (Thromboangiitis Obliterans) is an inflammatory type of obliterative vascular disease affecting chiefly the peripheral arteries and veins, especially of males during adult life. Although many agents, toxins and infections have been suggested, any clear explanation has not received general acceptance. Smoking is bad to this disease, the treatment of unrepaired ulcer in Buerger's disease is lumbar sympathectomy, and, when gangrene is present, amputation.

\section{Purpose :}

In Buerger's disease thrombous formation is one of the most essential pathological findings. In this paper the changes of blood coagulation and fibrinolysis in 82 cases of this disease was reported.

Methods :

The following coagulation parameters were examined; platelet adhesiveness by modified method of Hellem II, platelet aggregation induced with ADP or collagen, antithrombin III by single radial immunodiffusion and heparin resistance by modified method of Holger Madsen.

Results :

Out of 82 patients 3 cases were females and 79 males, mean age 43 and average age of onset of symptom was 38.8. Coagulation data were shown in Table 1 , and it was revealed that,

1) Primary bleeding time was prolonged slightly.

2) Second bleeding time was remained within normal.

3) APTT, PT were remained within normal but heparin resistance was increased and antithrombin III was decreased. Values of APTT as well as PT was not correlated with the severity of ulcer formation. The change of heparin

* 大阪大学医学部第二外科 [T553 大阪市福島区福島 $1-1-50$ ], Second Department of Surgery, Osaka University Medical School, Osaka, Japan. 
resistance was varied from $12 \mathrm{sec}$ to $400 \mathrm{sec}$, and appartently correlated with ulcer formation. In respective case, the clinical fluctuation of leg ulcer was well correlated with heparin resistance. Antithrombin III was decreased in these cases but increased after treatment not to correlate with ulcer formation itself.

Conclusion :

1) Heparin Resistance is increased to $26.8+8.9 \mathrm{sec}$ in Buerger's disease.

2) In the stage of ulcer formation both of heparin resistance and antithrombin III was increased, but heparin resistance was decreased and antithrombin III was increased when ulcer disappear. From these results we can consider that Buerger's disease will be under the thrombophilic condition.

\section{はじめに}

バージャー病 (Buerger's disease) は20〜40 歳男性の下肢に好発する原因不明の非特異性血 管炎である。臨床的には疼痛，潰瘍，壊死など 動脈の閉塞性病変による症状を呈し, 根本療法 あなくただいくつかの対象療法が行われている に過ぎない，終局的には，肢，趾切断を余儀な くされる症例が少なくない。

\section{I. 目 的}

バージャ一病は血管炎と血栓症を合併する一 連の疾患で血栓形成は本症に抒ける重要な病理 学的所見の一つである。そこで本症においては 血液の凝固, 線溶能に何らかの変化が起ってい るであろうことが推測される. 今回私達はバー ジャ一病82例について血液凝固, 線溶能のうち いくつかの凝固系を検討したのでその成績を報 告する.

\section{II. 方 法}

各検査は一般検査方法に従がったが，血小板 数は自動計数法, 粘着能は Hellem II 変法 ${ }^{4)}$, 血小板凝集能 (ADP, Collagen) は Evans 社 製 aggregometer ${ }^{5)}$ を使用した. とくにアンチ トロンビン III は一次免疫拡散法 (Single radial Immunodiffusion method) ${ }^{6)}$ にて测定し, ヘパ リン抵抗は Holger-Madsen ${ }^{1)}$ の変法 で 測定し た。

\section{III. 成 績}

バージャ一病82例の性別内訳は女性 3 例, 他
Table 1 Examination coagulation data of Buerger's disease

\begin{tabular}{l|c}
\hline APTT $(25 \sim 45 \mathrm{sec})$ & $34 \pm 9$ \\
PT $(80 \sim 120 \%)$ & $106 \pm 14$ \\
Heparin resistance $(32 \sim 36 \mathrm{sec})$ & $26.8 \pm 8.9$ \\
Antithrombin III $(25 \sim 45 \mathrm{mg} / \mathrm{dl})$ & $19 \pm 8$ \\
\hline
\end{tabular}

はすべて男性であり，平均年齢は 43.0 歳，初発 年齢は 38.8 歳，病悩期間は平均 5 年であった。 各検査成績を要約すると次のごとくである。一 次出血時間はやや延長，二次出血時間は正常で あった。凝固系については部分トロンボプラス チン時間 (Activated Partial Thromboplastin, Time, APTT), プロトロンビン 時間 (Proth rombin Time) はほぼ正常で，ヘパリン抵抗 (Heparin Resistance) は増強し，アンチトロン ビン III (Antithrombin III) は減少した。それぞ れの成績は表 1 亿示した。ヘパリン抵抗の増強 は血栓形成準備状態を作り出し血栓症を発症し やすい．またアンチトロンビン III の減少はへパ リン抵抗増強の場合之同様に血栓形成準備状態 を作り出し血栓症を発症しやすくする.

APTT の推移をみるとほぼ正常範囲内に留 まった. APTT と潰瘍の有無との間には一定 の傾向を認めなかった.

プロトロンビン時間の推移をみると APTT と同様にほぼ正常範囲内に留まり，またプロト ロンビン時間と潰痬の有無との間にも一定の傾 向を認めなかった.

ヘパリン抵抗の推移をみるとその值は大きく 変動し最低 12 秒から最高 400 秒におよんだ。へ 

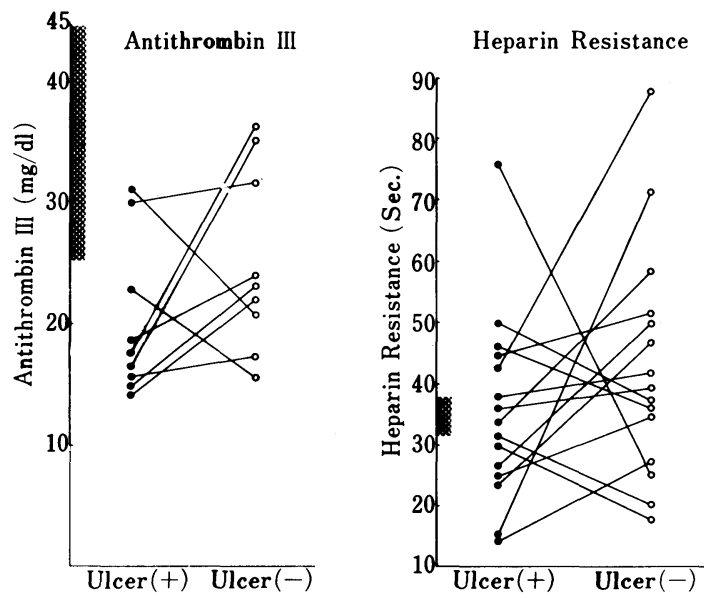

Fig. 1 Change of antithrombin III and heparin resistance correlated with formation and disappearance of ulcer in Buerger's disease.

パリン抵抗と潰瘍の有無との関係をみるとへパ リン抵抗が 32 秒以下では潰痬を有するあのは $45.9 \%$ を，潰瘍を有しないあのは $54.1 \%$ を占 めた．また正常範囲内（32〜36秒）ではそれぞ れ57.1\%，42.9\%を，さらに36秒以上ではそれ ぞれ23.7\%，76.3\%を占めた.すなわちへパリ ン抵抗が増強した時点では潰瘍を有する症例は 多く，一方減弱した時点では潰瘍を有する症例 が少ないという傾向を示した。

アンチトロンビン III の推移をみるとアンチト ロンビン III は全体として低值を示し治療により 高值に移行する傾向がみられた. アンチトロン ビン III と潰瘍の有無との関係をみるとアンチト ロンビン III が $25 \mathrm{mg} / \mathrm{d} l$ 以下では潰瘍を有するむ のは $35.3 \%$ ，潰瘍を有しないものは $64.7 \% を$ 占めた. また正常範囲内 $(25 \sim 45 \mathrm{mg} / \mathrm{d} l)$ では それぞれ $31.8 \% ， 68.2 \%$ 占めた.すなわちア ンチトロンビン III と潰瘍の有無との間にはとく に相関を認めなかった.

次に潰瘍が治療によって治療した症例のみを ピックアップしヘパリン抵抵拉よびアンチトロ ンビン III の推移を検討してみると, 図 1 亿示す ごとくヘパリン抵抗は15例中10例で減弱, 5 例 で増強した。 それぞれの増減の平均值は前者で +20.8秒, 後者でー19.4秒であった. またアン チトロンビン III は 9 例中 7 例で増加， 2 例で減

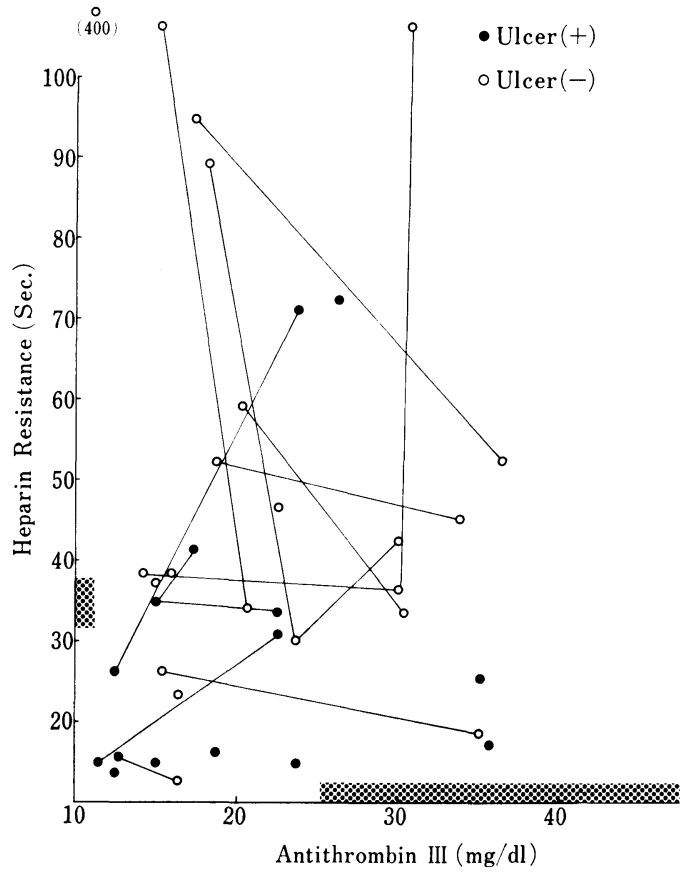

Fig. 2 The correlation between heparin resistance and antithrombin III

少した. それぞれの増減の平均值は前者で+ $9.0 \mathrm{mg} / \mathrm{d} l$, 後者で $-9.0 \mathrm{mg} / \mathrm{d} l$ であった.

ヘパリン抵抗とアンチトロンビン III との関係 をみると図 2 に示すごとく両者の間には相関を 認めなかった．次いで潰瘍との関係をみるとへ パリン抵抗が32秒以下执よびアンチトロンビン III が $25 \mathrm{mg} / \mathrm{d} l$ 以下の範囲内では潰瘍を有するす のは66.6\%を，潰瘍を有しないすのは33.4\%を 占めた。またそれぞれが 32 秒以下および $25 \mathrm{mg} /$ $\mathrm{d} l$ 以上の範囲内ではそれぞれ $50.0 \% ， 50.0 \%$ 占めた。またそれぞれが32秒以上， $25 \mathrm{mg} / \mathrm{d} l$ 以 下の範囲内ではそれぞれ $26.6 \% ， 73.4 \%$ 占め た。またそれぞれが32秒以上， $25 \mathrm{mg} / \mathrm{d} l$ 以上の 範囲内ではそれぞれ14.3\%，85.7\%を占めた。 すなわちへパリン抵抗が増強し，アンチトロン ビン III が減少した領域内ではやや潰瘍が多い傾 向を示した。

線溶系については各検查成績はほぼ正常範囲 内であった。

ての成績からみるとバージャ一病では血栓形 成準備状態にあり，潰瘍がある時にはその傾向 が一層強いように思われた。 


\section{結 論}

私達はバージャ一病82例について凝固系の検 査のうち APTT，プロトロンビン時間，ヘパリ ン抵抗，アンチトロンビン III の推移を検討した ところ次のような結論を得た。

1）本症ではへパリン抵抗は $26.8 \pm 8.9$ 梨で 増強, アンチトロンビン III $19 \pm 8$ で減少して いた。

2）潰瘍がある時期にはヘパリン抵抗は増強 し，アンチトロンビン IIIは減少し, 潰瘍が治癒 した時期にはへパリン抵抗は減弱し，アンチト ロンビン III は増加した。

3）本症では血栓形成準備状態にあるととが 推測される.
文献

1) Holger-Madsen, T.: The plasma heparin thrombin time. Acta Haemat., 21; 301 $315,1959$.

2) 三島好雄，他：昭和 50 年度厚生省特定疾患対 策ビュルガー病研究班報告書, p. 161，1976.

3）村上文夫, 大城孟, 他: Buerger 病に打 け る血液凝固, 線溶系について. 昭和 48 年度厚 生省特定疾患対策ビュルガー病研 究 班 報 告 書, p. 70, 1974.

4）血液検查 (医学書院), p. 467, 1972.

5) 臨床病理：特集 $27:$ p. 15 28, 1976.

6) 臨床病理：特集27: p. 191 192, 1976.

\section{のビタミンB ${ }_{12}$ 研究の完全なる集大成！}

\section{ビタミン B 12 一基礎と臨床}

編集 京都大学内科教授 内野治人 専門医24氏分担執筆 A 5 判 367頁 図157 表73 定価7,800円(干200円) -101 東京都干代田区神田多町 $2-11$ 科学 評論 社 振替口座束京 $7-102026$ 